\title{
Título da aplicação móvel: My life as a refugee
} (versão 1.1)

URL: http://mylifeasarefugee.org/game.html

Filipa Almeida Pestana

\section{OpenEdition}

\section{Journals}

Edição electrónica

URL: http://journals.openedition.org/rccs/6172

DOI: $10.4000 /$ rccs. 6172

ISSN: 2182-7435

\section{Editora}

Centro de Estudos Sociais da Universidade de Coimbra

\section{Edição impressa}

Data de publição: 1 dezembro 2015

Paginação: 191-192

ISSN: 0254-1106

\section{Refêrencia eletrónica}

Filipa Almeida Pestana, «Título da aplicação móvel: My life as a refugee (versão 1.1) », Revista Crítica de Ciências Sociais [Online], 108 | 2015, posto online no dia 16 dezembro 2015, consultado o 25 setembro 2020. URL : http://journals.openedition.org/rccs/6172 ; DOI : https://doi.org/10.4000/rccs 6172 


\section{Espaço Virtual}

\section{Título da aplicação móvel: My life as a refugee (versão 1.1) URL: http://mylifeasarefugee.org/game.html}

Criada pelo Alto Comissariado das Nações Unidas para os Refugiados (ACNUR) em 2012, a aplicação móvel "My life as a refugee" faz parte de uma ampla campanha dinamizada por esta agência das Nações Unidas, com o objetivo de sensibilizar para a situação dos refugiados no mundo. Inserindo-se num contexto de expansão da produção e utilização de aplicações móveis (na gíria inglesa apps) para fins sociais e/ /ou pedagógicos, e também no contexto atual de crise humanitária, "My life as a refugee" serve-se de um conceito inovador para transmitir uma mensagem poderosa - a de que ao processo de deslocação forçada e procura de asilo correspondem sempre decisões racionais e dilemáticas, equacionadas por homens e mulheres como "nós". Esta é pois uma aplicação que tem claramente como público-alvo o Norte global.

Centrada na ideia-chave de que "ninguém escolhe ser refugiado", "My life as a refugee" convida a refletir sobre o conjunto de dilemas, baseados em experiências reais, com que aqueles que decidem abandonar o seu país de origem para rumar a um destino mais seguro se veem confrontados. À semelhança de um jogo de computador, é possível escolher uma de três personagens, em circunstâncias muito distintas: uma jovem mãe prestes a dar à luz o seu terceiro filho, em plena guerra civil; uma ativista dos direitos das mulheres que as autoridades nacionais pretendem silenciar; e um adolescente do sexo masculino que sonha tornar-se médico mas teme ser forçado a juntar-se ao exército. Não existe qualquer referência espacial ou histórica, e as personagens não possuem nomes culturalmente identificáveis, embora seja de alguma forma claro que todos pertencem a países em desenvolvimento ou em transição. Depois de selecionada a personagem, o utilizador deve então tomar sucessivas decisões, tais como procurar ou abandonar um familiar morto em combate; optar entre trazer consigo pertences valiosos ou mantimentos; atravessar fronteiras legal ou ilegalmente. Todas as decisões acarretam consequências e influenciam o resultado final.

Além do seu cariz interativo, a aplicação possui também uma componente informativa mais tradicional, sendo disponibilizados ao longo do jogo pequenos parágrafos de contextualização bem como algumas curiosidades (e.g. "Sabias que o conhecido físico Albert Einstein era refugiado?"). Funciona ainda como mecanismo de angariação de fundos, já que permite fazer um donativo ao ACNUR no fim do jogo. "My life as a refugee", que está disponível para iPhone, iPad e Android, não pode nem pretende competir com outro tipo de software de entretenimento nem deve, por outro lado, contribuir para trivializar o tema em questão. Mas enquanto ferramenta virtual educacional, tem potencial para promover uma melhor compreensão das experiências associadas à migração forçada, sobretudo junto da comunidade não académica, como no caso dos jovens internautas. A aplicação beneficiaria, no entanto, com a inclusão de mais personagens, nomeadamente com 
razões de fuga menos "clássicas", como as alterações climáticas. Em todo o caso, esta e outras aplicações móveis reclamam cada vez mais espaço no debate crítico sobre o papel do ativismo virtual e sobre o uso das tecnologias de informação e comunicação na sensibilização para problemas sociais concretos.

Filipa Almeida Pestana

\section{Filipa Almeida Pestana}

Centre for Middle Eastern Studies, Lund University

Finngatan 16, 22362 Lund, Suécia

Contacto: filipa.almeidapestana@gmail.com 